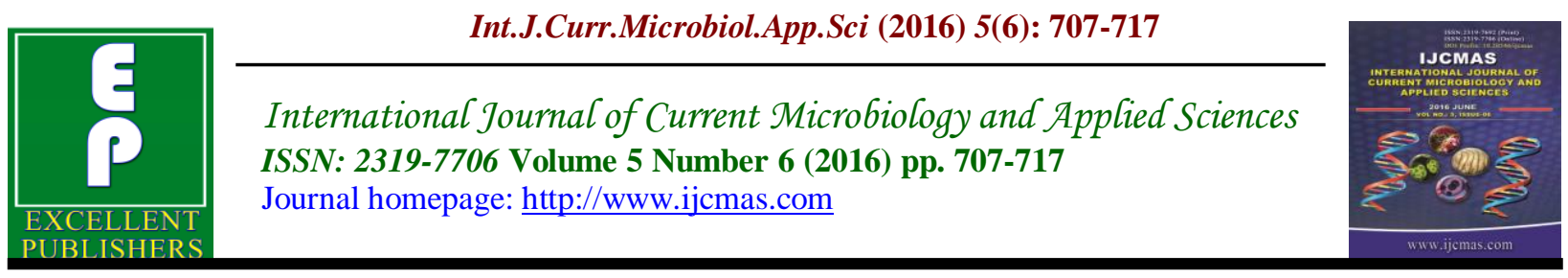

Original Research Article

http://dx.doi.org/10.20546/ijcmas.2016.506.077

\title{
Physico-Chemical and Microbial Analysis of Waste Water from different Industry and Cod Reduction Treatment of Industrial Waste Water by using Selective Microorganisms
}

\author{
H.S. Surti* \\ School of sciences, Gujarat University, Ahmedabad, Gujarat, India \\ *Corresponding author
}

\section{Keywords}

Waste water, physico-chemical and microbial analysis, COD reduction, microorganisms.

\section{Article Info}

Accepted:

24 May 2016

Available Online:

10 June 2016

\section{A B S T R A C T}

Water pollution is one of the major problem in a todays scenario. Polluted water is a liberated from any industrial place or which contains a high amount of hazardous compounds. This water is discarded into waterbodies like river, lake, etc. These waterbodies are the source of water use for various purpose. If this polluted water is discarded directly into the waterbodies it can causes serious effect on environment and $\mathrm{n}$ human life. This type of water pollution can also affect the ecosystem adversely. So, analysis before release of water form industry is essential. Therefore, primary, secondary and final treatment of waste water is carried out. Physical, chemical and microbial analysis of waste water performed which includes $\mathrm{pH}$, color, TDS, SS BOD, COD, oil and grease, chloride, sulphate, total coliform, fecal coliform, etc. Every industrial effluent contains high amount of organic matter which is hazardous to environment. Microorganisms use organic matter as a nutrient. Composition of waste water works as growth medium supplying sufficient nutrient for biological growth. The waste water plants are constructed to bring down the contamination level to acceptable quality level so that it can be easily discharged. Various physico-chemical techniques such as sedimentation, filtration, flotation, coagulation, etc. Have been studied in vast for waste water treatment but due to the limitation such as partial treatment, high cost, generation of secondary pollutants and use of chemical agents make the biological methods a favorable alternative for the removal of COD. Here, in my study, used Pseudomonas aeruginosa, Bacillus subtilis, Enterobactor aerogenes for COD reduction of pharmaceutical, textile, milk and food industrial waste water. Those organisms are highly efficient in COD reduction of industrial waste water up to $60-65 \%$ within few days.

\section{Introduction}

Pollution is one of the major challenges of today's civilization. In India, it is found that one-third of total water pollution comes in the form of industrial effluent discharge, solid wastes and other hazardous wastes.
Industrial wastewater presents a potential hazard to the natural water system. This wastewater contains many inorganic and organic matters, which are toxic to the various life forms of the ecosystem. 
Industrial activities generate a large number and variety of waste products. The nature of industrial waste depends upon the industrial processes in which they originate. The problem of adequately handling industrial waste waters is more complex and much more difficult because industrial waste water varies in nature from relatively clean rinse waters to waste liquors than are heavily laden with organic or mineral matter or with corrosive, poisonous, inflammable or explosive substances.

Pharmaceutical industry production includes raw material, antibiotics, variety of medicines and cosmetic products, which in turn generates the effluent containing constituents harmful to human and aquatic life. pharmaceutical industries do not generate uniform waste streams, due to the variety of medicines produced during any given manufacturing process. Though the volume of untreated or incompletely treated pharmaceutical industry wastewater is small, it contains a high level of pollutants because of the presence of nonbiodegradable organic matter such as antibiotics, other prescription drugs, non-prescription drugs, animal and plant steroids, reproductive hormones, betalactamides, anti-inflammatories, analgesics, lipid regulators, anti-depressants, cytostatic agents, personal care products, detergent metabolites, flame retardants, product of oil use and combustion and other extensively used chemicals, i.e. spent solvents, reaction residues, used filter media, etc., heavy metals (such as lead, mercury, cadmium, nickel, chromium) and other pollutants.

The milk industry generates between 3.739 to 11.217 million $\mathrm{m}^{3}$ of waste per year (i.e. 1 to 3 times the volume of milk processed). Waste water is generated in milk processing unit, mostly in pasteurization, homogenization of fluid milk and the production of dairy products such as butter, cheese, milk powder etc. Most of the milk processing unit use "clean in place" (CIP) system which pumps cleaning solutions through all equipment in this order water rinse; caustic solution (sodium hydroxide) wash, water rinse acid solution (phosphoric or Nitric acid) wash, water rinse, and sodium hypo-chlorite disinfectant.

The textile effluents contain trace metals like $\mathrm{Cr}, \mathrm{As}, \mathrm{Cu}$ and $\mathrm{Zn}$, which are capable of harming the environment (Eswaramoorthi $S$, Dhanapal, et al., 2008). Dyes in water give out a bad colour and can cause diseases like haemorrhage, ulceration of skin, nausea, severe irritation of skin and dermatitis (Nese, Sivri, Toroz, 2007) They can block the penetration of sunlight from water surface preventing photosynthesis (Laxman, 2009). Dyes also increase the biochemical oxygen demand of the receiving water and in turn reduce the reoxygenation process and hence hamper the growth of photoautotrophic organisms.

Textile production involves a number of wet processes that may use solvents. Emissions of volatile organic compounds (VOCs) mainly arise from textile finishing, drying processes, and solvent use.

In general, the numerous unit operations and processes to remove wastewater contaminants are grouped together to provide various levels of treatment. The treatment of water is divided into 3 parts:

1. Physical - primary methods are referred to physical or physical-chemical unit Operations. e.g. filtration, adsorption, air flotation, flocculation and sedimentation.

2. Biological - secondary referred to biological operations. e.g. aerobic, anaerobic and activated sludge. 
3. Chemical - advanced or tertiary referred to chemical or to combinations of all three e.g. Thermal oxidation (combustion), Chemical oxidation, Ion exchange, Chemical precipitation, incineration.

The use of conventional water and wastewater treatment processes becomes increasingly challenged with the identification of more and more contaminants, rapid growth of population and industrial activities, and diminishing availability of water resources. (Zhou $\mathrm{H}$ and D.W. Smith, 2001). The actual state performance of conventional methods is clearly not suitable to treat toxic, nonbiodegradable organic pollutants and new improved treatments have to be developed and tested. To overcome the inconveniences of conventional treatment methods, Advanced Oxidation Techniques (AOP's) have emerged in the last decades, in particular for the treatment of industrial wastewaters.

The major objective is to control pollution and the protection of the environmental quality. Monitoring of aqueous sample by various parameter from different sites of industrial plant to assess, monitor and to focus on the sites which are the main source, responsible for the water pollution. Collect the industrial waste water samples from specific industrial areas. Analysis of industrial waste water samples using physico-chemical and microbial parameters. In order to control the environmental pollution of different industries, have different methods to treat the waste and reuse it. The ancient methods employed for the treatment of waste water includes physical, chemical and thermal methods. But these treatment methods have disadvantages which includes huge labour requirement, high maintenance cost, low efficiency, huge equipment. In order to attain maximum efficiency in waste water treatment and reuse the water, an advanced technology has been developed and research is going on for better result which is known as bio remediation. (Dixit and Parmar 2013; Chang et al. 2008) Bioremediation is the process of using microorganisms to clean up harmful chemicals in the environment. When the microbes completely digest these chemicals, they change them into non-toxic products such as water and carbon dioxide. The automobile effluent parameters were analysed such as $\mathrm{pH}$, color, temperature, total solids, total dissolved solids, sulphate, chlorides, biological oxygen demand and chemical oxygen demand.

\section{COD Reduction Using Selective Microorganisms}

Chemical Oxygen Demand (COD) determines the oxygen requirement equivalent of organic matter that is susceptible to oxidation with the help of a strong chemical oxidant. It is an important, rapidly measured parameters as a means of measuring organic strength for streams and polluted water bodies. Microorganisms use organic matter as a nutrient. Composition of waste water works as growth medium supplying sufficient nutrient for biological growth. Every industrial effluent contains high amount of organic matter which is hazardous to environment. Various physicochemical techniques have been studied in vast for waste water treatment but due to the limitation such as partial treatment, high cost, generation of secondary pollutants and use of chemical agents make the biological methods a favourable alternative for the removal of COD.

Here, in this present study bacterial strains of Pseudomonas aeruginosa,Bacillus subtilis, Enterobactor aerogenes and mix culture of this three bacterial strains are used for COD reduction of waste water from pharmaceutical industry. The open reflux 
method is most suitable for COD measurement. The dichromate reflux method is preferred over procedures using other oxidants (e.g. potassium permanganate) because of its superior oxidizing ability. The organic matter gets oxidised completely by potassium dichromate $\left(\mathrm{K}_{2} \mathrm{Cr}_{2} \mathrm{O}_{7}\right)$ with silver sulphate as catalyst in the presence of concentrated $\mathrm{H}_{2} \mathrm{SO}_{4}$ to produce $\mathrm{CO}_{2}$ and $\mathrm{H}_{2} \mathrm{O}$. The excess $\mathrm{K}_{2} \mathrm{Cr}_{2} \mathrm{O}$ remaining after the reaction is titrated with ferrous ammonium sulphate $[\mathrm{Fe}$ $\left.\left(\mathrm{NH}_{4}\right)_{2}\left(\mathrm{SO}_{4}\right)_{2}\right]$. The dichromate consumed gives the oxygen $\left(\mathrm{O}_{2}\right)$ required for oxidation of the organic matter. The chemical reactions involved in the method are as under:

a. $2 \mathrm{~K}_{2} \mathrm{Cr}_{2} \mathrm{O}_{7}+8 \mathrm{H}_{2} \mathrm{SO}_{4} \rightarrow 2 \mathrm{~K}_{2} \mathrm{SO}_{4}+$ $2 \mathrm{Cr}_{2}\left(\mathrm{SO}_{4}\right)_{3}+8 \mathrm{H}_{2} \mathrm{O}+3 \mathrm{O}_{2}$

b. $\mathrm{C} 6 \mathrm{H} 12 \mathrm{O} 6+6 \mathrm{O} 2 \rightarrow 6 \mathrm{CO} 2+6 \mathrm{H} 2 \mathrm{O}$

c. $\mathrm{Cr}_{2} \mathrm{O}_{7^{--}}+6 \mathrm{Fe}+++14 \mathrm{H}+\rightarrow 6 \mathrm{Fe}++++$ ${ }_{2} \mathrm{Cr}_{3}++7 \mathrm{H}_{2} \mathrm{O}$

\section{Methods}

Take a pure culture of Bacillus subtilis, Pseudomonas aeruginosa, Enterobactor aerogenes.

Subculture those organisms in different nutrient media and also prepare a culture suspension.

Prepare Nutrient broth containing different concentration of samples, e.g.5\%,10\% ,15\%. Than autoclave it.

Add $5 \mathrm{ml}$ culture suspension of each organism in different $5 \%$ concentrated sample containing nutrient broth. Than incubate it at $37^{\circ} \mathrm{C}$ for $48 \mathrm{~h}$ after $48 \mathrm{~h}$ incubation take loop full sample from each organisms inoculated 5\% nutrient broth containing sample and streak on nutrient agar plate and incubate it at $37^{\circ} \mathrm{C}$ for $24 \mathrm{~h}$.
After $24 \mathrm{~h}$ incubation observe the growth of particular organism in each nutrient agar plate.

Prepare a culture suspension from this nutrient agar plate and $5 \mathrm{ml}$ culture suspension transfer into different $10 \%$ concentrated sample containing nutrient broth. Than incubate it at $37^{\circ} \mathrm{C}$ for $48 \mathrm{~h}$.

After $48 \mathrm{~h}$ repeat above steps again. Now observe the growth of organisms than it means the organisms are favorable with sample.

\section{Preparation of Sample}

Take $200 \mathrm{ml}$ sample into $500 \mathrm{ml}$ Erlenmeyer flask and autoclave it at 15 p.s.i. at $121^{\circ} \mathrm{C}$. After autoclave the sample leave it for Cool down. Inoculate the sample with $30 \mathrm{ml}$ culture suspension prepared from $15 \%$ sample containing nutrient broth. Incubate flask at room temperature on shaker at 200 rpm. Now after $24 \mathrm{~h}$ take sample for cod reduction analysis by open reflux method.

Continue this process for 5 days.

Observe the result and plot a cod reduction graph.

\section{Calculation}

Normality of FAS $=\mathrm{N}$ of potassium Dichromate

$\times$ Vol. of $\mathrm{k} 2 \mathrm{Cr} 2 \mathrm{O} 7$

$\mathrm{ml}$ of FAS used

Factor $=\mathrm{N}$ of FAS $\times 8000$

COD mg/l = A.D $\times$ Factor

Sample taken (ml)

1.Volatile straight - chain aliphatic compounds

2. Presence of halogens may interfere.

3. Chloride, Bromide and Iodide ions.

4. Nitrate (NO2) 


\section{Results and Discussion}

The 10 sample of industrial effluent tested for the physicochemical parameters like color, pH, TDS, SS, chloride, sulphate, COD, oil and grease, Ammonical nitrogen, MPN - Total coliform \& Fecal coliform found that few the samples have in permissible limits and few samples having higher value than the normal limit indicating, that further treatment is required before the release of water into the main water resources. The results are indicated in Table no. 2

\section{pH}

The $\mathrm{pH}$ is a logarithmic scale generally used to express the acidic, alkaline or neutral nature of a solution. The pollution load in most of the chemical industries are in large quantity in the form of acid and alkali in manufacturing unit. The wide variation in the $\mathrm{pH}$ value of effluent can affect the rate of biological reaction and survival of various microorganisms. In the present study the $\mathrm{pH}$ of final outlet all samples are within range.

\section{Color}

If water is colored its uses can be limited and the aesthetics of the situation can lead to many complaints and possible breaches of discharge limits. The disturbance of biological processes in surface water induced by changes in color and intensity is a serious problem

\section{Total Dissolved Solids and Total Suspended Solids}

$T D S$ content in water is a measure for salinity. A large number of salts like carbonates, bicarbonates, chlorides, sulphates, phosphates, and nitrates of calcium, magnesium, sodium, potassium, iron, and manganese, etc. are present. A high content of dissolved solid elements affects the density of water, influences osmo regulation of freshwater in organisms, reduces solubility of gases (like oxygen) and utility, of water for drinking, irrigational, and industrial purposes.

\section{Chloride}

Chloride occurs in all natural waters in widely varying concentrations. Chloride in excess (> $250 \mathrm{mg} / \mathrm{L}$ ) imparts a salty taste to water and people who are not accustomed to high chlorides may be subjected to laxative effects. The chloride content in the river water samples ranged between $224 \mathrm{mg} / \mathrm{L}$ in downstream and $222 \mathrm{mg} / \mathrm{L}$ in upstream of the river.

\section{Biochemical Oxygen Demand}

BOD is measure of biodegradable organic material present in wastewater and can be defined as the amount of oxygen required by the microorganisms in stabilizing the biologically degradable organic matter under aerobic conditions.

\section{Chemical Oxygen Demand}

COD analysis is a measurement of the oxygen-depletion capacity of a water sample contaminated with organic waste matter. Specifically, it measures the equivalent amount of oxygen required to chemically oxidize organic compounds in water. 
Table.1 Materials and methods of physical, chemical and microbial parameters

\begin{tabular}{|c|c|c|}
\hline PARAMETERS & MATERIALS & METHODS \\
\hline \multicolumn{3}{|c|}{ PHYSICAL PARAMETERS } \\
\hline $\mathrm{pH}$ & Electric $\mathrm{pH}$ meter & Electrometric method \\
\hline Color & Color comparator & $\begin{array}{l}\text { Visual comparison method (APHA ed. 22, } \\
\text { pg. } 2-5 \text { ) }\end{array}$ \\
\hline TDS \& SS & Filter assembly, filter paper & $\begin{array}{l}\text { Filtration \& Gravimetric method (APHA ed. } \\
22 \text {, pg. 2- } 65,66 \text { ) }\end{array}$ \\
\hline \multicolumn{3}{|c|}{ CHEMICAL PARAMETERS } \\
\hline BOD & $\begin{array}{l}\text { Magnesium sulphate, Calcium chloride, } \\
\text { ferric chloride, starch solution, sodium } \\
\text { sulphate, phosphate buffer, seed culture }\end{array}$ & $\begin{array}{l}\text { Alkali azide method, titrimetric method } \\
\text { (APHA ed. 22, pg. 5- 4) }\end{array}$ \\
\hline COD & $\begin{array}{l}\text { Concentrated } \mathrm{H} 2 \mathrm{SO} 4 \text { with } \mathrm{AgSO} 4 \text {, } \\
\text { Standard potassium dichromate }(0.25 \mathrm{~N}) \text {, } \\
\text { Ferrous ammonium sulphate }(0.25 \mathrm{~N}) \text {, } \\
\text { HgSO4 powder }\end{array}$ & $\begin{array}{l}\text { Open reflux method (APHA ed. 22, pg. } 5 \text { - } \\
\text { 16) }\end{array}$ \\
\hline$O \& G$ & $\begin{array}{l}\text { Hexane, sodium sulphate, HCL, separation } \\
\text { funnel }\end{array}$ & $\begin{array}{l}\text { Alkali Azide Method, Titrimetric method } \\
\text { (APHA ed. 22, pg. } 5-38 \text { ) }\end{array}$ \\
\hline Chloride & Potassium chromate, $\mathrm{AgSO} 4(0.014 \mathrm{~N})$ & $\begin{array}{l}\text { Argentometric Method (APHA ed. 22, pg. } 4 \\
-72 \text { ) }\end{array}$ \\
\hline Sulphate & Conditioning reagent, $\mathrm{BaCL} 2, \mathrm{D} / \mathrm{W}$ & $\begin{array}{l}\text { Turbidimetric method (APHA ed. 22, pg. 4- } \\
\text { 188) }\end{array}$ \\
\hline $\begin{array}{l}\text { Ammonical } \\
\text { nitrogen }\end{array}$ & $\begin{array}{llll}\text { Alkali } & \text { solution, } & \text { boric } & \text { acid, } \\
\text { phenolphthalein, } \mathrm{H} 2 \mathrm{SO} 4(0.02 \mathrm{~N}) & \end{array}$ & $\begin{array}{l}\text { Ammonia distillation \& titrimetric method } \\
\text { (APHA ed. 22, pg. } 4-110 \text { ) }\end{array}$ \\
\hline \multicolumn{3}{|c|}{ MICROBIAL PARAMETERS } \\
\hline Total coliforms & $\begin{array}{l}\text { Lauryl Tryptose Broth, Brilliants Green } \\
\text { Bile Broth }\end{array}$ & $\begin{array}{l}\text { Multiple tube fermentation method (APHA } \\
\text { ed. } 22 \text {, pg. } 9-66 \text { ) }\end{array}$ \\
\hline Fecal coliforms & EC Broth & $\begin{array}{l}\text { Multiple tube fermentation method (APHA } \\
\text { ed. } 22 \text {, pg. } 9-74 \text { ) }\end{array}$ \\
\hline
\end{tabular}

Table.2 Results of all physico-chemical and microbial parameters

\begin{tabular}{|c|c|c|c|c|c|c|c|c|c|c|}
\hline Samples & pH & Colour & Chloride & Sulphate & Bod & Cod & O\&g & Nh3n & Tds & Ss \\
\hline \multicolumn{8}{|c|}{ DAIRY } \\
\hline $\mathbf{1}$ & 7.84 & blackish & 1890 & 240 & 744 & 1712 & 2 & 0.56 & 4092 & 16 \\
\hline $\mathbf{2}$ & 8.62 & light black & 1072 & 150 & 4 & 12 & 3.8 & 19.18 & 2340 & 22 \\
\hline \multicolumn{8}{|c|}{ TEXTILE } \\
\hline $\mathbf{8}$ & 12.09 & blackish & 990 & 570 & 80 & 275 & 2.8 & 2.82 & 3364 & 158 \\
\hline $\mathbf{4}$ & 7.54 & greenish & 1485 & 1070 & 211 & 456 & & 31.02 & 5693 & 313 \\
\hline \multicolumn{8}{|c|}{ FOOD \&FOOD } \\
\hline $\mathbf{5}$ & 8.1 & greyish & 608 & 502 & 110 & 321 & & 29.93 & 2328 & 128 \\
\hline $\mathbf{6}$ & 5.84 & light yellowish & 507 & 123 & 946 & 1338 & 2.2 & 13.68 & 2230 & 640 \\
\hline \multicolumn{8}{|c|}{ PHARMACEUTICALS } \\
\hline $\mathbf{7}$ & 7.84 & colourless & 204 & 160 & 54 & 155 & 16.3 & 19.18 & 928 & 64 \\
\hline $\mathbf{8}$ & 6.98 & blackish & 700 & 237 & 568 & 5452 & 3.4 & 53.58 & 1780 & 4280 \\
\hline
\end{tabular}


Table.3 Results of cod reduction

\begin{tabular}{|l|l|l|l|l|}
\hline \multicolumn{1}{|c|}{ SAMPLE } & & $\mathbf{1}^{\text {ST }}$ DAY & $\mathbf{1 5}^{\mathrm{TH}}$ DAY & \% REDUCTION \\
\hline $\begin{array}{l}\text { Pharmaceutical } \\
\text { industry }\end{array}$ & Pseudomonas spp. & 3096 & 1548 & $50 \%$ \\
\hline & Bacillus spp. & 3096 & 2388 & $24 \%$ \\
\hline & Enterobactor spp. & 3096 & 2726 & $18 \%$ \\
\hline & MIXCULTURE & 3096 & 1920 & $62 \%$ \\
\hline & & & & \\
\hline Milk industry & Pseudomonas spp. & 2279 & 878 & $64.75 \%$ \\
\hline & Bacillus spp. & 2388 & 1285 & $50.0 \%$ \\
\hline & Enterobactor spp. & 2365 & 1802 & $24.0 \%$ \\
\hline & MIXCULTURE & 2111 & 743 & $71.03 \%$ \\
\hline & Pseudomonas spp. & 1518 & 582 & $68.9 \%$ \\
\hline & Bacillus spp. & 1726 & 992 & $46.9 \%$ \\
\hline & Enterobactor spp. & 1776 & 1305 & $30.3 \%$ \\
\hline & MIXCULTURE & 1490 & 479 & $74.7 \%$ \\
\hline & Pseudomonas spp. & 1843 & 1028 & $49.2 \%$ \\
\hline & Bacillus spp. & 1922 & 1435 & $29.0 \%$ \\
\hline & Enterobactor spp. & 1972 & 1584 & $26.0 \%$ \\
\hline & MIXCULTURE & 1827 & 744 & $63.3 \%$ \\
\hline
\end{tabular}

\section{COD REDUCTION}

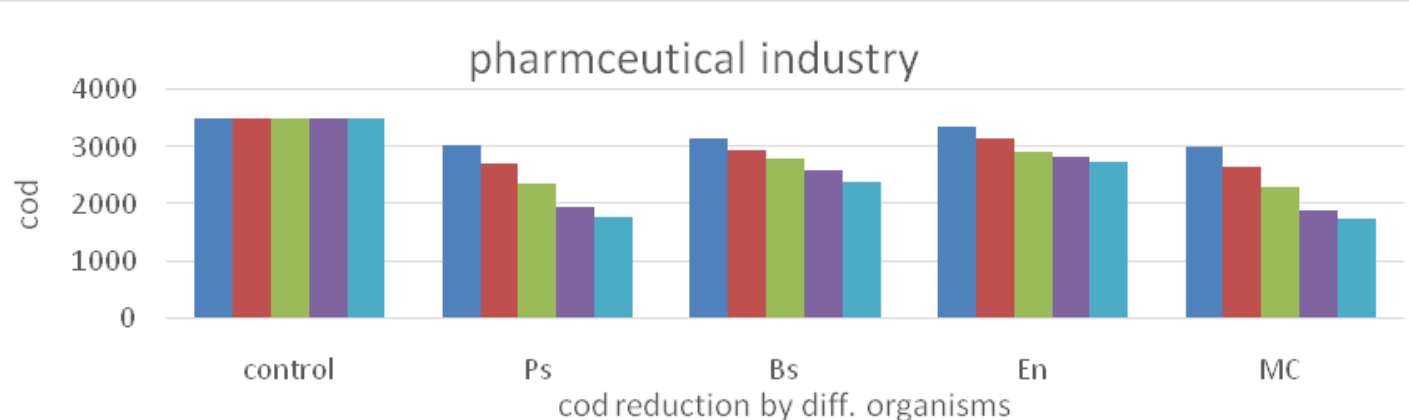

GRAPH: -Shows that COD reduction of pharmaceutical waste water by different organisms are different such as

Pseudomonas spp. Shows reduction during $1^{\text {st }}$ day $-2 \%, 3^{\text {rd }}$ day $-13 \%, 6^{\text {th }}$ day $-22 \%, 9^{\text {th }}$ day $-32 \%$, $12^{\text {th }}$ day - $44 \%, 15^{\text {th }}$ day $-50 \%$.

Bacillus spp. Shows reduction during $1^{\text {st }} d a y-2 \%, 3^{\text {nd }} d a y-10 \%, 6^{\text {th }}$ day $-15 \%, 9^{\text {th }} d a y-20 \% 12^{\text {th }} d a y-$ $26,15^{\text {thday }}-24 \%$.

Enterobactor spp. Shows that $1^{\text {st }}$ day $-1 \%, 3^{\text {rd }}$ day $-4 \%, 6^{\text {th }}$ day $-10 \%, 9^{\text {th }}$ day $-17 \%, 12^{\text {th }}$ day $19 \%, 15^{\text {th }}$ day $-18 \%$.

Mix culture shows during $1^{\mathrm{s}^{\mathrm{t}}}$ day $-2 \%, 3^{\text {rd }}$ day $-13 \%, 6^{\text {th }}$ day $-24 \%, 9^{\text {th }}$ day $-34 \%, 12^{\text {th }}$ day $-46 \%, 15^{\text {th }}$ day $-62 \%$. 


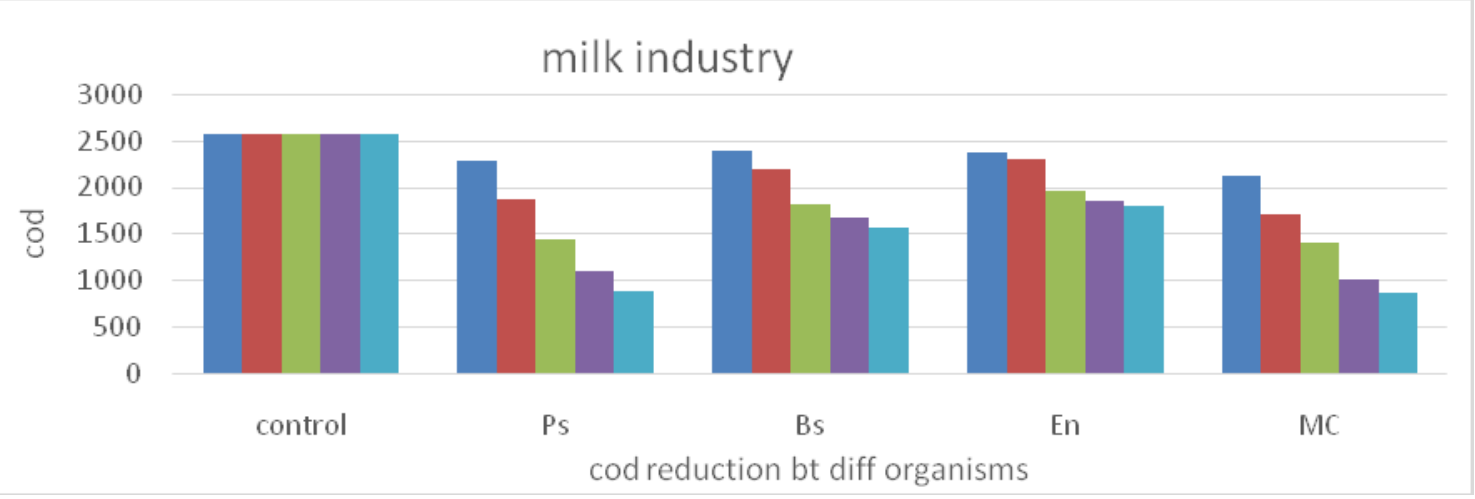

GRAPH: -Shows that COD reduction of milk industrial waste water by different organisms are different such as

Pseudomonas spp. Shows reduction during 1 st day $-2 \%, 3$ rd day $-11 \%, 6$ th day $-27 \%$, 9 th day $44 \%, 12$ th day - $58 \%, 15$ th day $-65 \%$.

Bacillus spp. Shows reduction during 1 st day $-2 \%, 3$ nd day $-7 \%, 6$ th day $-15 \%$, 9th day $-30 \% 12$ th day $-35,15$ th day $-39 \%$.

Enterobactor spp. Shows that 1 st day $-1 \%, 3$ rd day $-8 \%, 6$ th day $-10 \%, 9$ th day $-24 \%, 12$ th day $28 \%, 15$ th day $-30 \%$.

Mix culture shows during 1 st day $-2 \%$, 3rd day $-18 \%, 6$ th day $-33 \%, 9$ th day $-45 \%, 12$ th day $-60 \%, 15$ th day $-66 \%$.

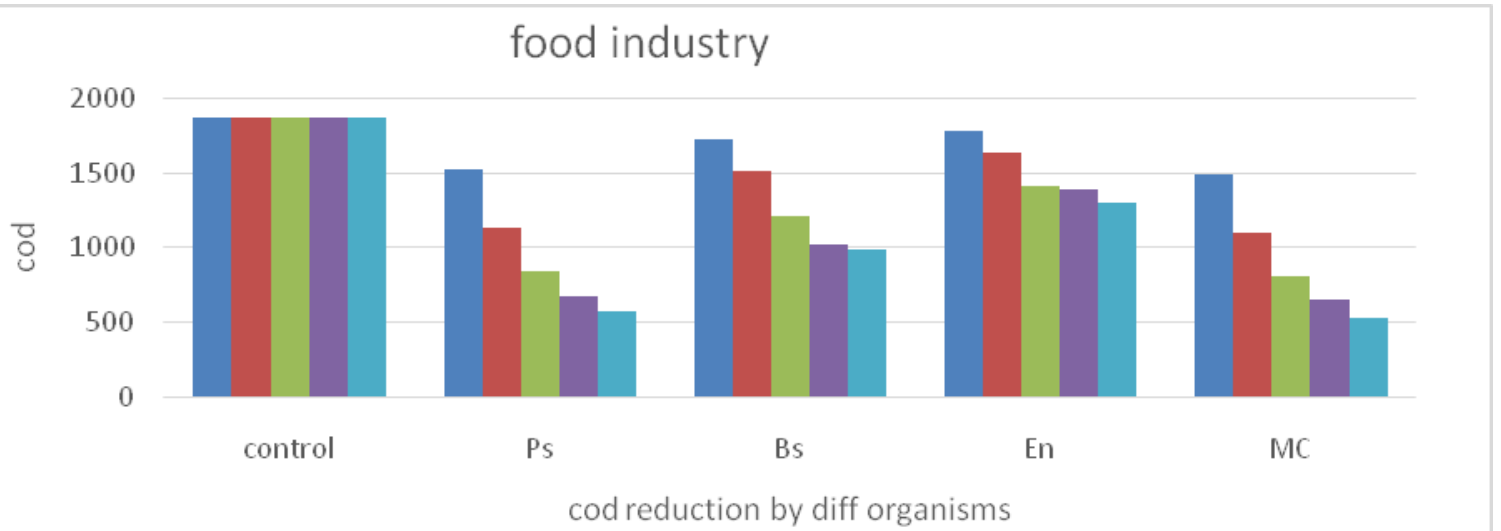

GRAPH: -Shows that COD reduction of food industrial waste water by different organisms are different such as

Pseudomonas spp. Shows reduction during 1 st day $-2 \%, 3$ rd day $-19 \%$, 6th day $-39 \%$, 9th day $55 \%, 12$ th day - $64 \%, 15$ th day $-69 \%$.

Bacillus spp. Shows reduction during 1 st day $-2 \%, 3$ nd day $-8 \%, 6$ th day $-19 \%$, 9 th day $-35 \% 12$ th day $-45 \%, 15$ th day $-47 \%$.

Enterobactor spp. Shows that 1 st day $-1 \%, 3$ rd day $-5 \%, 6$ th day $-13 \%, 9$ th day $-25 \%, 12$ th day $26 \%, 15$ th day $-30 \%$.

Mix culture shows during 1 st day $-2 \%$, 3rd day $-20 \%$, 6th day $-41 \%, 9$ th day $-57 \%, 12$ th day $-65 \%, 15$ th day $-72 \%$. 


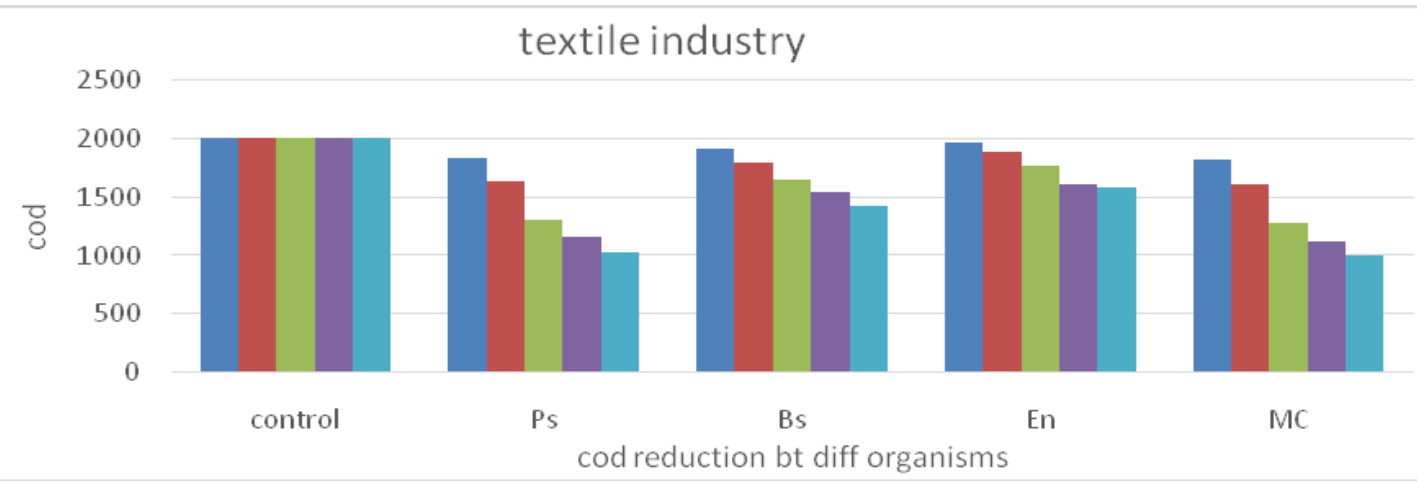

GRAPH: -Shows that COD reduction of textile industrial waste water by different organisms are different such as

Pseudomonas spp. Shows reduction during 1 st day $-2 \%, 3$ rd day $-9 \%$, 6th day $-18 \%, 9$ th day $-35 \%$, 12 th day $-42 \%, 15$ th day $-49 \%$.

Bacillus spp. Shows reduction during 1 st day $-2 \%$, 3nd day $-4 \%$, 6th day $-10 \%$, 9 th day $-18 \% 12$ th day $-23 \%, 15$ th day $-29 \%$.

Enterobactor spp. Shows that 1 st day $-1 \%$, 3rd day $-2 \%, 6$ th day $-6 \%, 9$ th day $-12 \%$, 12 th day $19 \%, 15$ th day $-21 \%$.

Mix culture shows during 1 st day $-2 \%$, 3rd day $-9 \%$, 6th day $-20 \%$, 9th day $-36 \%, 12$ th day $-44 \%, 15$ th day $-50 \%$.

\section{Oil and Grease}

It is important here to note that oil which forms a surface film on the river can coat plants and animals reducing oxygenation from the atmosphere above. The film of oil that floats over the water body affects the transmission of light through the water body there by disturbing the process of photosynthesis in the aquatic plants. In animals, oil coating can destroy the insulating properties of fur and feathers. Oil bio accumulates in the higher animals and further enters the food chain.

In conclusion, waste water is a polluted water liberated from any industrial place or which contains high amount of hazardous compounds. This water is discarded into river. River is the source of water use for various purpose. If this polluted water is discarded directly into the river it can causes serious effect on environment and on human life. This type of water pollution can also affect the ecosystem adversely. So, analysis before release of water from industry is essential.

Therefore, primary, secondary and final treatment of waste water is carried out. Physical, chemical and microbial analysis of waste water performed, which includes $\mathrm{pH}$, colour, BOD, COD, TDS, oil and grease, MPN, chloride, sulphate, Ammonical nitrogen etc. which samples are within the range that disposed into the river while which samples are not within rang their effluent treatment is necessary.

The study of bioremediation of industrial effluents by bacteria is an effective method for treating pharmaceutical effluent and can be a good substitute for conventional remediation processes. For improved commercial use of microorganisms in suitable carriers will prove economical for their use. However, if this can be developed in large scale it will be useful for the treatment of not only the pharmaceutical effluent but industrial effluent of any kind. 
The results of the present study conclude that the treatment of industrial effluents by using Pseudomonas aeruginosa, Bacillus subtilis and Enterobactor aerogenes are able to reduce COD by utilizing organic matter. It's evident from the results that the cod content of effluent after shaking condition was significantly reduced about 60\%-70\% by mix culture (Pseudomonas sp., Bacillus sp., Enterobactor sp.) and Pseudomonas sp., individually reduced COD about $45 \%-50 \%$, while Bacillus sp. And Enterobactor sp. Reduced COD by $30 \%-40 \%$ and $25 \%$, respectively.

It can be concluded by these study that mixed culture of above mentioned three bacterial sp. are highly proficient to reduce COD so it can be used at industrial level for effluent treatment.

\section{References}

APHA. (American Public Health Association) and American Water Works Association (1998). Standard Methods for the Examination of Water and Wastewater, 20th Edition, New York.

Glassmeyer, S.T., Kolpin, D.W., Furlong, E.T., Focazio, M.J. 2008. Environmental presence and persistence of pharmaceuticals: an overview. Fate of pharmaceuticals in the environment and in water treatment systems, 3-51.

Halling-Sørensen, B., Nielsen, S.N., Lanzky, P.F., Ingerslev, F., Lützhøft, H.H., Jørgensen, S.E. 1998. Occurrence, fate and effects of pharmaceutical substances in the environment-A review. Chemosphere, 36(2): 357-393.

Imran, H. 2005. Wastewater monitoring of pharmaceutical industry: treatment and reuse options. Electron. J. Environ. Agric. Food Chem, 4(4): 994-1004.

Joss, A., Zabczynski, S., Göbel, A., Hoffmann, B., Löffler, D., McArdell, C.S., Siegrist, H. 2006. Biological degradation of pharmaceuticals in municipal wastewater treatment: proposing a classification scheme. Water Res., 40(8): 1686-1696.

Kavitha, R.V., Murthy, V.K., Makam, R., Asith, K.A. 2012. Physico-chemical analysis of effluents from pharmaceutical industry and its efficiency study. Int. J. Eng. Res. Appl., 2(2): 103-110.

Rana, R.S., Singh, P., Kandari, V., Singh, R., Dobhal, R., Gupta, S. 2014. A review on characterization and bioremediation of pharmaceutical industries' wastewater: An Indian perspective. Applied Water Sci., 1-12.

Rosen, M., Welander, T., Löfqvist, A., Holmgren, J. 1998. Development of a new process for treatment of a pharmaceutical wastewater. Water Sci. Technol., 37(9): 251-258.

Watrous, R.M. 1947. Critical review: Health hazards of the pharmaceutical industry. British J. Industrial Med., 4(2): 111.

Zhou, P., Su, C., Li, B., Qian, Y. 2006. Treatment of high-strength pharmaceutical wastewater and removal of antibiotics in anaerobic and aerobic biological treatment processes. $J$. Environ. Engi., 132(1): 129-136.

\section{How to cite this article:}

Surti, H.S., 2016. Physico-Chemical and Microbial Analysis of Waste Water from different Industry and Cod Reduction Treatment of Industrial Waste Water by using Selective Microorganisms. Int.J.Curr.Microbiol.App.Sci. 5(6): 707-716. doi: http://dx.doi.org/10.20546/ijcmas.2016.506.077 